\title{
Purification of a Distinct Placental Lactogen Receptor, a New Member of the Growth Hormone/Prolactin Receptor Family
}

\author{
Michael Freemark and Marty Comer \\ Department of Pediatrics, Duke University Medical Center, Durham, North Carolina 27710
}

\begin{abstract}
Recent findings from this laboratory suggest that the biological actions of placental lactogen (PL) in mammalian fetal tissues are mediated through binding of the hormone to a distinct and unique PL receptor. We have now purified this receptor from fetal and maternal sheep liver, characterized its binding to PL, growth hormone (GH), and prolactin (PRL), and determined its molecular weight by SDS-PAGE and by affinity cross-linking techniques. Soluble extracts containing specific, high-affinity $\left(K_{d} 0.5 \mathrm{nM}\right)$ PL binding activity were prepared by incubating ovine fetal and maternal liver microsomes with $1 \%$ Triton X-100. The detergent solubilized PL receptor was purified two- to threefold by ion-exchange chromatography and an additional twofold by gel exclusion chromatography on Sepharose $6 \mathrm{~B}$. The $\mathrm{PL}$ receptor was then purified 75,000 - to 125,000 -fold by affinity chromatography using a column of ovine PL (oPL) coupled to Affi-Gel 10. The molecular weight of the oPL receptor as determined by SDS-PAGE and by cross-linking techniques was $44,000 \pm 2,000$ (range 40,000$48,000)$. The purified receptor bound ${ }^{125} \mathrm{I}-0 \mathrm{PL}$ specifically and with high affinity $\left(K_{d} 0.5 \mathrm{nM}\right)$ but did not bind either radiolabeled ovine GH or ovine PRL. In addition, in competition studies using ${ }^{125} \mathrm{I}-\mathrm{oPL}$ as the radioligand, the purified PL receptor bound unlabeled oPL with a potency 30-50 times greater than that of ovine GH and 500-1,000 times greater than that of ovine PRL.

These findings demonstrate the presence of a specific $P L$ receptor in fetal and maternal sheep liver. The PL receptor, together with the GH and PRL receptors, constitute a family of distinct but related hormone receptors that differ in their relative affinities for PL, GH, and PRL. Changes in the expression of the three receptors may mediate changes in the hormonal control of growth during the transition from fetal to postnatal life.
\end{abstract}

\section{Introduction}

Placental lactogen (PL) ${ }^{1}$ is a polypeptide hormone that has structural and functional similarities to growth hormone $(\mathrm{GH})$

Address reprint requests to Dr. Freemark, Box 3080, Duke University Medical Center, Durham, NC 27710. 1988

Received for publication 5 July 1988 and in revised form 25 October

1. Abbreviations used in this paper: $\mathrm{GH}$, growth hormone; $\mathrm{oGH}, \mathrm{oPL}$, and oPRL, ovine growth hormone, placental lactogen, and prolactin; PL, placental lactogen; PRL, prolactin.

J. Clin. Invest.

(C) The American Society for Clinical Investigation, Inc.

$0021-9738 / 89 / 03 / 0883 / 07 \$ 2.00$

Volume 83, March 1989, 883-889 and prolactin (PRL). Studies by many investigators during the past 25 yr suggested that PL functions predominantly or exclusively as a maternal hormone during pregnancy, exerting effects on maternal carbohydrate and lipid metabolism and the production of insulin-like growth factor $I(1,2)$. Recent studies from this and other laboratories, however, indicate that PL may also play a role in the regulation of fetal metabolism and the control of fetal growth. PL has direct anabolic effects on fetal amino acid and carbohydrate metabolism (3-8) and stimulates ornithine decarboxylase activity (9), DNA synthesis (10, $11)$, and somatomedin production $(10,12,13)$ in fetal tissues. In contrast, most studies demonstrate that GH and PRL have little or no somatotropic activity in the fetus $(3,9,12,14-17)$. Since the biological effects of PL in fetal tissues are similar to those of GH in postnatal tissues, PL appears to function as a "fetal GH."

Previous investigators postulated that the biological actions of PL in tissues of postnatal animals are mediated through binding of the hormone to GH (somatotropic) or PRL (lactogenic) receptors (18-21). Studies from this laboratory, however, strongly suggest that the biological actions of PL in fetal tissues are mediated through binding of the hormone to a distinct and unique PL receptor. The specific binding of radiolabeled PL to ovine fetal liver $(8,22,23)$ and to human fetal skeletal muscle (24) greatly exceeds that of radiolabeled $\mathrm{GH}$ or PRL, and PL binding sites in ovine and human fetal tissues have high affinity for PL and low affinity for GH and PRL. In addition, the molecular weight of the PL binding site in fetal sheep liver $(38,000-47,000 \mathrm{~mol} w \mathrm{wt})$ as determined by affinity cross-linking techniques (23) differs from that of the $\mathrm{GH}$ binding site in postnatal sheep liver $\left(54,000 / 118,000 \mathrm{~mol}^{-} \mathrm{wt}\right)$. These findings suggest that PL receptors in fetal tissues differ in structure and function from GH and PRL receptors in postnatal tissues.

In recent investigations (25) we demonstrated that treatment of sheep liver microsomes with Triton X-100 solubilizes the PL binding site but not the $\mathrm{GH}$ binding site. We have exploited this differential solubilization of PL and GH binding sites in order to purify the PL receptor from fetal and maternal liver. We have characterized the binding of the purified receptor to PL, GH, and PRL and have determined its molecular weight by SDS-PAGE and by affinity cross-linking techniques.

\section{Methods}

Hormones. Ovine placental lactogen (oPL, lot 3-23) was prepared from sheep cotyledons as previously described (26). Ovine growth hormone (OGH, NIH-GH-S12) and ovine prolactin (oPRL, NIH-P-S14) were obtained from the National Hormone and Pituitary Program, National Institute of Arthritis, Digestive Disease and Kidney. The preparations of oPL and $O G H$ utilized for the present studies were previously shown to stimulate amino acid transport in postnatal rat diaphragm with similar potencies (27). 
Preparation of radiolabeled hormones. ${ }^{125} \mathrm{I}-\mathrm{oPL},{ }^{125} \mathrm{I}-\mathrm{oGH}$, and ${ }^{125}$ I-oPRL were prepared using 1,3,4,6-tetrachloro 3,6-diphenyl glycouril (Iodo-Gen, Pierce Chemical Co., Rockford, IL) as the catalyst, as previously described $(8,22,23)$. Each preparation of ${ }^{125} \mathrm{I}-\mathrm{oPL}$ and ${ }^{125} \mathrm{I}-\mathrm{oGH}$ exhibited $>25 \%$ specific binding to hepatic membranes from lactating rabbits at $20 \mathrm{~h}$ of incubation at $4^{\circ} \mathrm{C}$ using $250 \mu \mathrm{g}$ of hepatic membrane protein per assay tube (20). Each preparation of ${ }^{125} \mathrm{I}$-oPRL exhibited $>20 \%$ specific binding to rabbit mammary tissue under similar conditions (19).

Preparation of liver microsomes. Four pregnant Dorset ewes at 131-140 d of gestation (term $=145 \mathrm{~d}$ ) were killed rapidly by the intrathecal administration of sodium pentobarbital. Livers of fetal and pregnant sheep were rapidly removed, frozen in liquid nitrogen, and stored at $-70^{\circ} \mathrm{C}$. Frozen liver samples were subsequently thawed and homogenized in an ice-cold solution of $0.3 \mathrm{M}$ sucrose and $2 \mathrm{mM}$ EDTA, pH 7.4, containing phenylmethylsulfonylfluoride (PMSF, 1 $\mathrm{mM})$, leupeptin $(10 \mu \mathrm{g} / \mathrm{ml})$, and aprotinin $(20 \mathrm{IU} / \mathrm{ml})$. Liver microsomes were prepared by differential centrifugation as previously described (23).

Detergent extraction of liver microsomes. Detergent extracts of fetal and pregnant sheep liver were prepared by incubating hepatic microsomes from fetal and pregnant sheep for $\mathbf{3 0 ~} \mathrm{min}$ at room temperature in $25 \mathrm{mM}$ Tris- $\mathrm{HCl}$, pH 7.6, containing $1 \%$ Triton X-100, $1 \mathrm{mM}$ PMSF, $10 \mu \mathrm{g} / \mathrm{ml}$ leupeptin, and $20 \mathrm{IU} / \mathrm{ml}$ aprotinin. The suspension was then centrifuged at $100,000 \mathrm{~g}$ for $60 \mathrm{~min}$ at $4^{\circ} \mathrm{C}$. The supernatant (soluble fraction) was used in binding assays within $12 \mathrm{~h}$ of preparation or stored frozen at $-70^{\circ} \mathrm{C}$ to avoid precipitation.

Receptor assays. The binding of radiolabeled oPL, oGH, and oPRL to crude homogenates, microsomal fractions, and Triton-soluble extracts of fetal and maternal liver was performed in plastic $12 \times 75$ test tubes using methods described previously (25). Samples were suspended in $25 \mathrm{mM}$ Tris- $\mathrm{HCl}$, pH 7.6, containing $10 \mathrm{mM} \mathrm{MgCl}_{2}$ and $0.1 \%$ bovine serum albumin and were incubated with radiolabeled oPL $(0.1-0.2 \mathrm{nM}, \sim 75,000 \mathrm{cpm})$ for $24 \mathrm{~h}$ at $4^{\circ} \mathrm{C}$. Radiolabeled oPL bound to hepatic membranes was separated from free ${ }^{125} \mathrm{I}$-oPL by centrifugation at $3,000 \mathrm{~g}$. Radiolabeled oPL bound to detergent-solubilized oPL receptors was separated from free radioligand by precipitation with $8 \%$ polyethylene glycol (25).

Ion-exchange chromatography. Preliminary experiments demonstrated that the oPL receptor bound to diethylaminoethyl cellulose (DE-52) at $\mathrm{pH}$ 6.5-10 and was eluted with buffer containing $0.4 \mathrm{M}$ $\mathrm{NaCl}$. $\mathrm{NaCl}$ eluates containing the highest specific activity (specific binding per milligram of protein) were obtained when Triton extracts were applied to DE-52 at pH 8.0. Consequently in subsequent experiments, soluble detergent extracts of fetal or maternal liver were dialyzed against $50 \mathrm{mM}$ Tris- $\mathrm{HCl}$ containing $0.1 \%$ Triton $\mathrm{X}-100$ at $\mathrm{pH}$ 8.0. Aliquots of the dialyzed extract were then applied to a column $(20$ $\times 2.5 \mathrm{~cm}$ ) of DE-52 previously equilibrated in $50 \mathrm{mM}$ Tris- $\mathrm{HCl}, \mathrm{pH}$ 8.0 , containing $0.1 \%$ Triton. The column was washed with 3 vol of equilibrating buffer, and receptor binding material was eluted in a stepwise fashion with equilibrating buffer which contained $0.4 \mathrm{M}$ $\mathrm{NaCl}$. Fractions containing oPL binding activity were pooled, concentrated by ultrafiltration on a Centriprep microconcentrator $(30,000$ mol wt cutoff, Amicon Corp., Danvers, MA) and dialyzed against 25 $\mathrm{mM}$ Tris- $\mathrm{HCl}, \mathrm{pH} 7.6$, containing $0.1 \%$ Triton (Tris-Triton).

Sepharose chromatography. An 8-ml aliquot of the concentrated DE-52 eluate containing oPL binding activity was applied to a column $(91 \times 1.5 \mathrm{~cm})$ of Sepharose 6B which had been equilibrated previously with Tris-Triton at $4^{\circ} \mathrm{C}$. The sample was then eluted from the Sepharose column with cold Tris-Triton at a rate of $16 \mathrm{ml} / \mathrm{h}$, and $2.4-\mathrm{ml}$ fractions were collected. Individual fractions containing oPL binding activity were pooled for use in affinity chromatography.

Affinity chromatography. Affinity chromatography of the oPL receptor was performed using a column of purified oPL coupled to Affi-Gel 10. The oPL-Affi-Gel was generated by incubating $1 \mathrm{mg}$ of purified oPL (lot 7-11) dissolved in $8 \mathrm{ml}$ of $0.1 \mathrm{M} \mathrm{NaHCO}_{3}, \mathrm{pH} 8.3$ with $2.5 \mathrm{ml}$ of Affi-Gel 10 for $16 \mathrm{~h}$ at $4^{\circ} \mathrm{C}$. Under these conditions, $\sim 85 \%$ of the oPL was bound covalently to the Affi-Gel 10 . The
oPL-Affi-Gel was incubated with $400 \mu$ l of $1 \mathrm{M}$ ethanolamine, $\mathrm{pH}$ 8.0, for $1 \mathrm{~h}$ at $4^{\circ} \mathrm{C}$ and then washed over a Buchner funnel with $50 \mathrm{ml}$ of each of the following solutions in sequential order: $0.1 \mathrm{M} \mathrm{NaHCO}_{3}$; $0.1 \mathrm{M} \mathrm{NaHCO}_{3}$ containing $8 \mathrm{M}$ urea (ultrapure); $0.1 \mathrm{M} \mathrm{NaHCO}_{3} ; 0.1$ $\mathrm{M} \mathrm{NaHCO}_{3}$ containing $5 \mathrm{M}$ guanindine $\mathrm{HCl}$ (ultrapure); $0.1 \mathrm{M}$ $\mathrm{NaHCO}_{3} ; 2 \mathrm{M} \mathrm{NaCl}$ in $0.05 \mathrm{M} \mathrm{Na}$ acetate, pH 4.0;0.1 $\mathrm{M} \mathrm{NaHCO}_{3}$; $0.2 \mathrm{M} \mathrm{NaH}_{2} \mathrm{PO}_{4}$; Tris-Triton; and Tris-Triton containing $5 \mathrm{M} \mathrm{MgCl}_{2}$. The oPL-Affi-Gel was then incubated for $2 \mathrm{~h}$ at $4^{\circ} \mathrm{C}$ in Tris-Triton containing $20 \mathrm{U} / \mathrm{ml}$ aprotinin and $0.3 \mathrm{mM}$ PMSF. After this incubation, the gel was washed with Tris-Triton, then Tris-Triton containing $6 \mathrm{M}$ urea and finally Tris-Triton containing $5 \mathrm{M} \mathrm{MgCl}_{2}$ in preparation for incubation with Sepharose fractions containing oPL binding activity.

The oPL-Affi-Gel $(2.5 \mathrm{ml})$ was incubated with the pooled Sepharose eluate (total volume $16 \mathrm{ml}$ in Tris-Triton) for $24 \mathrm{~h}$ at $4^{\circ} \mathrm{C}$ in the presence of $10 \mathrm{mM} \mathrm{MgCl}, 20 \mathrm{IU} / \mathrm{ml}$ aprotinin and $0.1 \mathrm{mM}$ PMSF. After this incubation, the oPL-Affi-Gel was washed with $600 \mathrm{ml}$ of cold Tris-Triton and poured into a $5 \times 1.5 \mathrm{~cm}$ column. Protein bound to the affinity column was then eluted with $6 \mathrm{ml}$ of Tris-Triton containing $5 \mathrm{M} \mathrm{MgCl}_{2}$ at $23^{\circ} \mathrm{C}$. $1-\mathrm{ml}$ fractions were collected on ice and then dialyzed at $4^{\circ} \mathrm{C}$ against Tris-Triton. Fractions containing oPL binding activity were pooled and stored at $-70^{\circ} \mathrm{C}$.

Iodination of the purified receptor. $50 \mu \mathrm{l}$ of the affinity purified oPL

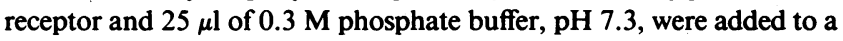
$12 \times 75$ glass tube coated with $1 \mu \mathrm{g}$ of Iodo-Gen. The iodination reaction was initiated by the addition of $20 \mu \mathrm{Ci}$ of iodine-125 in $25 \mu \mathrm{l}$ of phosphate buffer. After the mixture was shaken every $30 \mathrm{~s}$ for $4 \mathrm{~min}$, the contents of the tube were removed and analyzed by SDS-PAGE.

$S D S-P A G E$. Samples containing the iodinated oPL receptor were boiled for $5 \mathrm{~min}$ in electrophoresis sample buffer $(60 \mathrm{mM}$ Tris- $\mathrm{HCl}$, pH 6.8 , containing $3 \%$ SDS, $10 \%$ glycerol, $6 \mathrm{M}$ urea, $0.001 \%$ bromphenol blue, with or without $5 \% \beta$-mercaptoethanol). The mixtures were centrifuged at $3,000 \mathrm{~g}$ for $5 \mathrm{~min}$ and the samples were then analyzed on a $12.5 \%$ polyacrylamide gel using the discontinuous buffer system described by Laemmli (28) at a constant $70 \mathrm{~V}$ for $18 \mathrm{~h}$. After drying, the gels were autoradiographed at $-70^{\circ} \mathrm{C}$ using Kodak XAR-2 film and an enhancing screen. The apparent molecular weights of the radiolabeled proteins were determined by comparison with the relative migration of prestained molecular weight standards which had been applied to the gel (myosin 200,000; $\alpha$-macroglobulin, 180,000; $\beta$-galactosidase, 116,000; fructose-6-phosphate kinase, 84,000; pyruvate kinase, 58,000; fumarase, 48,500, lactate dehydrogenase, 36,500; and triosephosphate isomerase, 26,600, Sigma Chemical Co., St. Louis, MO).

In order to analyze the noniodinated, affinity-purified receptor by SDS-PAGE, it was necessary to concentrate active fractions and thereby maximize the recovery of protein. A 2-ml aliquot of affinitypurified receptor in Tris-Triton was concentrated by ultrafiltration on a Centricon microconcentrator (10,000-mol wt cutoff, Amicon Corp.). The concentrated sample $(50-100 \mu \mathrm{l})$ was dialyzed against $200 \mathrm{vol}$ of Tris-Triton, boiled in electrophoresis sample buffer, and analyzed on a $12.5 \%$ polyacrylamide gel as described in the preceding paragraph. The gel was stained with silver using the method of Oakley et al. (29). The molecular weight of the stained protein was estimated by comparing its migration on the gel with that of prestained molecular weight standards. The quantity of purified receptor applied to the gel was estimated by comparing the intensity of the staining of the receptor with that of the molecular weight standard using a densitometer.

Cross-linking of the purified receptor to radiolabeled oPL. Crosslinking was performed by a modification of the method of Spencer et al. (30). Affi-Gel eluates containing oPL binding activity were dialyzed against $25 \mathrm{mM}$ Hepes, $10 \mathrm{mM} \mathrm{MgCl}_{2}, \mathrm{pH}$ 7.6. Aliquots of the dialyzed receptor were incubated for $24 \mathrm{~h}$ at $4^{\circ} \mathrm{C}$ with ${ }^{125} \mathrm{I}-\mathrm{oPL}(500,000 \mathrm{cpm}$, $\sim 0.5 \mathrm{nM})$ in the presence or absence of excess $(1 \mu \mathrm{g})$ unlabeled oPL. Hormone-receptor complexes were then precipitated with polyethylene glycol as described previously (25). The pellets were dissolved in a solution of $0.4 \mathrm{mM}$ disuccinimidyl suberate in $25 \mathrm{mM}$ Hepes, $10 \mathrm{mM}$ $\mathrm{MgCl}_{2}, \mathrm{pH} 7.6$, and incubated for $30 \mathrm{~min}$ on ice. Aliquots of the 
reaction mixtures were boiled in electrophoresis sample buffer and analyzed on a $7.5 \%$ SDS-polyacrylamide gel. The gels were dried and subjected to autoradiography for $24 \mathrm{~h}$ at $-70^{\circ} \mathrm{C}$. The molecular weights of the radioactive hormone-receptor complexes were estimated by comparison with prestained molecular weight standards.

Data analysis. The binding of ${ }^{125} \mathrm{I}-\mathrm{oPL}$ to crude homogenates, microsomal fractions, and soluble detergent extracts of fetal and maternal liver was examined in the presence or absence of varying concentrations ( $0.1 \mathrm{ng}$ to $10 \mu \mathrm{g}$ per tube) of unlabeled $\mathrm{OPL}, \mathrm{OGH}$, and $\mathrm{OPRL}$. The total binding of ${ }^{125} \mathrm{I}-\mathrm{OPL}$ was expressed as the percent of iodinated hormone bound to hepatic membranes or detergent extracts. Specific binding was calculated by subtracting the amount of binding which occurred in the presence of excess (1-10 $\mu \mathrm{g}$ ) unlabeled hormone (nonspecific binding) from the total binding. The number and affinity of hormone binding sites, and the relative potencies of oPL, OGH, and oPRL in competing for binding to these sites, were estimated by analysis of competitive binding data using the LIGAND computer program (31) adapted for the IBM PC by McPherson (32). All comparisons of the potencies of the various hormones were performed using membrane preparations or detergent extracts pooled from the same sheep liver. In all experiments, the binding of ${ }^{125} \mathrm{I}$-oPL to hepatic membranes or to Triton-soluble fractions was determined in triplicate samples and was expressed relative to the protein content (33) of the membrane suspension. The statistical significance between sample means was tested by analysis of variance.

\section{Results}

Soluble extracts of fetal and maternal liver were prepared by incubating sheep hepatic microsomes with $1 \%$ Triton X-100 in Tris buffer. Detergent extracts prepared in this manner contained specific, high-affinity $\left(\dot{K}_{d} 0.5 \mathrm{nM}\right)$ PL binding activity but little or no specific GH or prolactin binding activity (25).

The PL receptor was purified from the detergent extracts by ion-exchange chromatography, size exclusion chromatography, and affinity chromatography. The various chromatographic procedures yielded qualitatively similar results with extracts of fetal or maternal liver (Tables I and II). Chromatography of soluble Triton extracts on DE-52 at $\mathrm{pH} 8.0$ provided a two- to threefold purification of the PL receptor, and chromatography of the DE-52 eluate on Sepharose 6B provided an additional twofold purification. The PL receptor was eluted from Sepharose 6B as a broad peak of binding activity with an approximate molecular weight of 130,000 (Fig. 1). The overall recoveries of fetal and maternal oPL binding activity from DE-52 and Sepharose 6B were $75-81 \%$ and $47-53 \%$, respectively.

Table I. Purification of the PL Receptor from Fetal Liver

\begin{tabular}{lccccc}
\hline \multicolumn{1}{c}{ Step } & Protein & Activity & $K_{\mathrm{d}}$ & Purification & Recovery \\
\hline & $m g$ & fmol/mg protein & $n M$ & - fold & $\%$ \\
Microsomes & 233 & 47 & 0.37 & - & - \\
1\% Triton & 214 & 49 & 0.52 & 1.0 & 92 \\
DE-52, pH 8 & 80.8 & 103 & 0.56 & 2.2 & 76 \\
Sepharose 6B & 25.8 & 208 & 0.55 & 4.4 & 49 \\
oPL-Affi-Gel & $\sim 0.0003$ & $\sim 5,840,000$ & 0.48 & $\sim 124,000$ & 16
\end{tabular}

The oPL receptor was purified from detergent extracts of fetal liver at $137 \mathrm{~d}$ of gestation. Estimates of the degree of purification following affinity chromatography are based on estimates of the amount of receptor recovered as determined by densitometric analysis of polyacrylamide gels. Qualitatively similar results were obtained using tissues of fetal lambs at 131 and $133 \mathrm{~d}$ of gestation.
Table II. Purification of the PL Receptor from Maternal Liver

\begin{tabular}{lccccc}
\hline \multicolumn{1}{c}{ Step } & Protein & Activity & $K_{\mathrm{d}}$ & Purification & Recovery \\
\hline & $m g$ & fmol/mg protein & $n M$ & -fold & $\%$ \\
Microsomes & 315.5 & 149 & 0.55 & - & - \\
1\% Triton & 297 & 143 & 0.69 & 0.85 & 91 \\
DE-52, pH 8 & 98.4 & 387 & 0.54 & 2.6 & 81 \\
Sepharose 6B & 30.6 & 813 & 0.59 & 5.1 & 53 \\
oPL-Affi-Gel & $\sim 0.0011$ & $\sim 12,820,000$ & 0.61 & $\sim 86,000$ & 30 \\
\hline
\end{tabular}

The oPL receptor was purified from detergent extracts of maternal liver at $137 \mathrm{~d}$ of gestation. Estimates of the degree of purification after affinity chromatography are based on estimates of the amount of receptor recovered as determined by densitometric analysis of polyacrylamide gels. Qualitatively similar results were obtained using tissues of pregnant sheep at 131 and $133 \mathrm{~d}$ of gestation.

After ion-exchange and size-exclusion chromatography, the PL receptor was purified 75,000- to 125,000 -fold by affinity chromatography using a column of ovine PL coupled to Affi-Gel 10. Soluble extracts of fetal and maternal liver were incubated with oPL-Affi-Gel for $24 \mathrm{~h}$ at $4^{\circ} \mathrm{C}$, and material which had bound to the affinity column was eluted with buffer containing $5 \mathrm{M} \mathrm{MgCl}_{2}$. Fractions were dialyzed against TrisTriton and then assayed for specific oPL binding activity. As shown in Fig. 2, the oPL receptor bound to the oPL affinity column and was eluted with $5 \mathrm{M} \mathrm{MgCl}_{2}$. The overall recovery of oPL binding activity following ion-exchange, Sepharose and affinity chromatographies was $16-30 \%$; a higher recovery might have been obtained if we had used more than $1 \mathrm{mg}$ of oPL in the generation of the affinity column.

When Affi-Gel fractions containing oPL binding activity were concentrated and analyzed by SDS-PAGE, the predominant protein observed had a molecular weight of $44,000 \pm 2,000$ (Fig. 3). The presence of $\beta$-mercaptoethanol in the electrophoresis sample buffer did not alter the apparent molecular weight of the protein. When Affi-Gel fractions containing oPL binding activity were iodinated and then analyzed

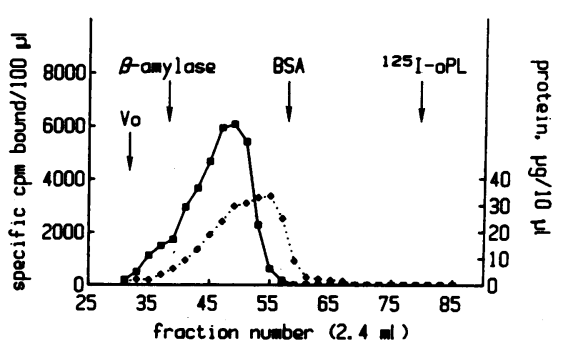

Figure 1. Chromatography of the oPL receptor on Sepharose 6B. Microsomal fractions of maternal liver at $137 \mathrm{~d}$ of gestation were solubilized with Triton X-100, applied to a DE-52 column $(20 \times 2.5 \mathrm{~cm})$ and eluted with $0.4 \mathrm{M} \mathrm{NaCl}$. DE-52 fractions containing oPL binding activity were pooled, concentrated, and dialyzed against Tris-Triton. An 8-ml aliquot of the pooled eluate was applied to a column $(91 \times 1.5 \mathrm{~cm})$ of Sepharose 6B and eluted with Tris-Triton. Sepharose fractions were assayed for oPL binding activity $(\bullet)$ and for protein content $(\diamond)$. Molecular weight standards used to calibrate the column included dextran blue $(\mathrm{Vo}), \beta$-amylase $(200,000 \mathrm{~mol} \mathrm{wt})$, bovine serum albumin (BSA, 68,000 mol wt), and ${ }^{125} \mathrm{I}-\mathrm{oPL} 22,000 \mathrm{~mol}$ $w t)$. Values represent the mean of triplicate values. The $S E$ in all cases was less than or equal to $10 \%$ of the mean value. Similar findings were noted using soluble extracts of fetal liver at $137 \mathrm{~d}$ of gestation. 


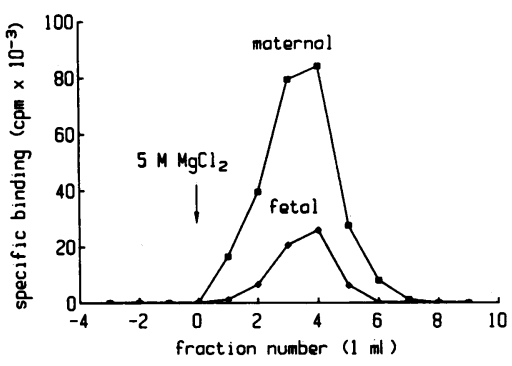
described in Methods. The affinity column was then washed with $600 \mathrm{ml}$ of cold Tris-Triton, and material which had bound to oPLAffi-Gel was eluted with Tris-Triton containing $5 \mathrm{M} \mathrm{MgCl}_{2}$. Affi-Gel fractions were dialyzed against Tris-Triton and assayed for oPL binding activity. Values represent the mean of triplicate values. In each case, the SE was < $15 \%$ of the mean value. Similar findings were noted using soluble extracts of maternal and fetal liver at $133 \mathrm{~d}$ of gestation.

by SDS-PAGE, a single protein band with $43,000 \mathrm{~mol}$ wt was observed (Fig. 4, lanes $F$ and $M 1$ ). To determine whether this 43,000-mol wt protein represented the oPL receptor, fractions containing the iodinated protein were subjected to affinity chromatography a second time and analyzed by SDS-PAGE. Under these conditions, a radiographic band with $43,000 \mathrm{~mol}$ wt was also observed (Fig. 4, lane $M 2$ ), suggesting that the iodinated protein contained PL binding activity.

Affi-Gel fractions containing the $44,000-$ mol wt protein bound ${ }^{125} \mathrm{I}-\mathrm{oPL}$ specifically and with high affinity $\left(K_{\mathrm{d}} 0.6 \mathrm{nM}\right.$, Fig. 5, inset) but did not specifically bind radiolabeled oGH or oPRL in parallel experiments. The specific binding of radiolabeled oPL in experiments using $120 \mu \mathrm{l}$ of the dialyzed $\mathrm{MgCl}_{2}$ eluate (estimated to contain $2.5-5 \mathrm{ng}$ of the $44,000-\mathrm{mol} \mathrm{wt}$ protein) was $4.5-6.0 \%$. In experiments using $350 \mu \mathrm{l}$ of the dialyzed $\mathrm{MgCl}_{2}$ eluate, the specific binding of radiolabeled oPL was as high as $16 \%$. In competition studies using ${ }^{125} \mathrm{I}-\mathrm{oPL}$ as the radioligand (Fig. 6), the potency of oPL in competing for binding to the purified oPL receptor greatly exceeded that of oGH or oPRL. The PL receptor bound unlabeled oPL with a potency 30-50 times greater than that of $\mathrm{OGH}$ and 500-1,000 times greater than that of oPRL. Epidermal growth factor (500 $\mathrm{ng} / \mathrm{ml})$ and insulin $(1 \mu \mathrm{M})$ did not compete with ${ }^{125} \mathrm{I}-\mathrm{oPL}$ in the binding assay.

Cross-linking of ${ }^{125} \mathrm{I}$-oPL to the affinity-purified receptor yielded a radioactive protein complex with molecular weight

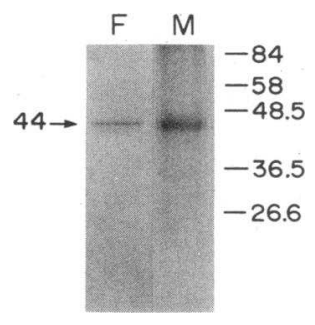

Figure 3. SDS-PAGE of the affinity-purified oPL receptor. The oPL receptor was purified from maternal $(M)$ and fetal $(F)$ liver at $137 \mathrm{~d}$ of gestation. Affi-Gel fractions containing oPL binding activity were concentrated, dialyzed against TrisTriton, boiled in electrophoresis sample buffer, and analyzed on a $12.5 \%$ polyacrylamide gel under nonreducing $(M)$ or reducing $(F)$ conditions. The gels were stained with silver, and the molecular weights of the stained proteins were estimated by comparison with molecular weight standards applied to the gel. Estimates of the molecular weight of the oPL receptor using extracts of fetal and maternal liver at 131 and $133 \mathrm{~d}$ of gestation ranged from 40,000 to 48,000 .

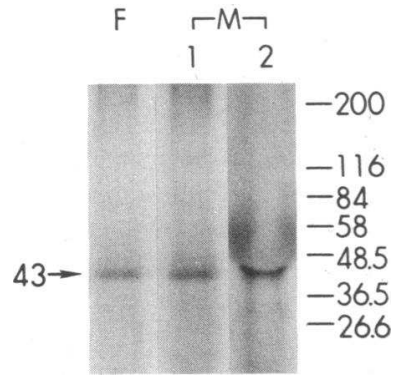

Figure 4. SDS-PAGE of the iodinated oPL receptor. The oPL receptor from fetal $(F)$ and maternal $(M)$ liver was purified as described in Figs. 1 and 2. Affi-Gel fractions containing oPL binding activity (see Fig. 2) were iodinated under the conditions described in Methods. The iodinated receptor was then analyzed on a $12.5 \%$ polyacrylamide gel under reducing conditions (lanes $F$ and $M-1$ ). Iodinated material was rechromatographed on oPL-Aff-Gel, and fractions containing radioactivity were pooled, dialyzed against Tris Triton, and analyzed by SDS-PAGE under reducing conditions (lane $M-2)$.

67,000 (Fig. 7, lane 1). The 67,000-mol wt radioactive complex was not observed when incubations were performed in the presence of a 1000-fold excess of unlabeled oPL (Fig. 7, lane 2 ). Since the molecular weight of oPL is $\sim 22,000$, the molecular weight of the oPL receptor estimated by affinity crosslinking was $\sim 45,000$.

\section{Discussion}

We have purified a 44,000 $\pm 2,000$-mol wt protein from soluble detergent extracts of fetal and maternal sheep liver. Five lines of evidence suggest that this 44,000-mol wt protein is the PL receptor or a component of the PL receptor: first, Affi-Gel fractions that contained predominantly the 44,000-mol wt protein bound radiolabeled oPL specifically and with high affinity but did not specifically bind radiolabeled $O G H$ or oPRL; secondly, Affi-Gel fractions containing the 44,000-mol wt protein, like microsomal fractions of ovine fetal liver $(22,23)$, bound oPL with a potency 30-50 times greater than that of oGH and 500-1,000 times greater than that of oPRL; thirdly, the iodinated 44,000 -mol wt protein re-bound to the oPL affinity column; fourthly, cross-linking of radiolabeled oPL to

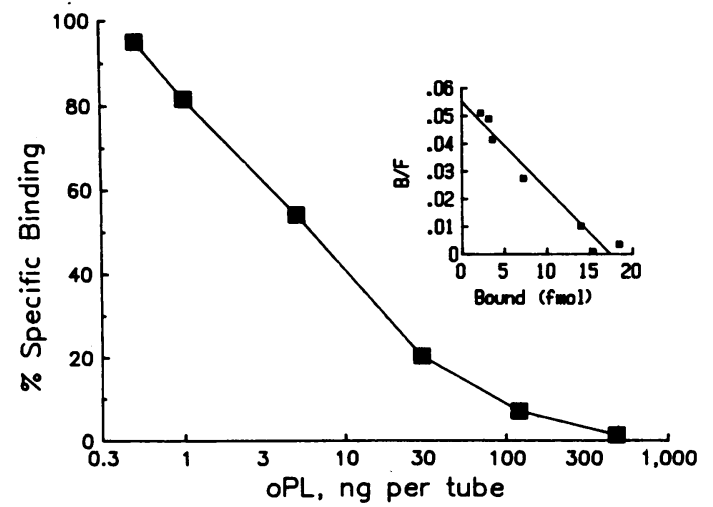

Figure 5. Binding of radiolabeled oPL to the purified PL receptor. The PL receptor was purified from the liver of a pregnant sheep at $133 \mathrm{~d}$ of gestation. Aliquots $(120 \mu \mathrm{l})$ of material that eluted from the oPL affinity column were incubated for $24 \mathrm{~h}$ at $4^{\circ} \mathrm{C}$ with ${ }^{125} \mathrm{I}$-oPL $(75,000 \mathrm{cpm}, \sim 0.2 \mathrm{nM})$ in the presence or absence of increasing amounts of unlabeled oPL ( $0.5 \mathrm{ng}$ to $2 \mu \mathrm{g})$. Values represent the means of duplicate values. The specific binding of radiolabeled oPL under the conditions described above was $5.9 \%$. The binding of oPL to the PL receptor was analyzed by the method of Scatchard (inset) using the LIGAND computer program (31). 


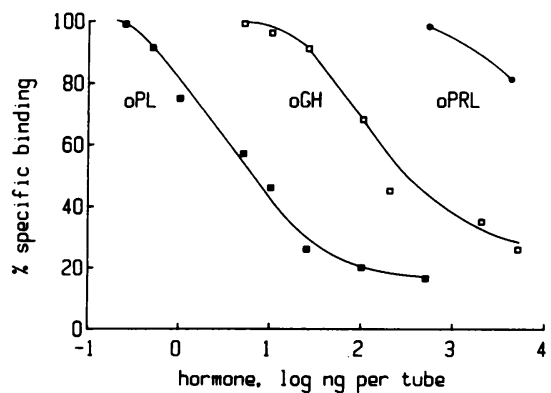

Figure 6. Effects of unlabeled oPL, oGH, and oPRL on the binding of ${ }^{125} \mathrm{I}$-oPL to the affinity-purified oPL receptor. The oPL receptor from maternal liver at $137 \mathrm{~d}$ of gestation was purified by ion-exchange chromatography, gel exclusion chromatography, and affinity chromatography. Affi-Gel fractions containing oPL binding activity were pooled and incubated for $24 \mathrm{~h}$ at $4^{\circ} \mathrm{C}$ with ${ }^{125} \mathrm{I}-\mathrm{oPL}(0.2 \mathrm{nM}$, $\sim 65,000 \mathrm{cpm}$ ) as well as various amounts of unlabeled oPL, oGH, and oPRL. Values represent the means of triplicate values. In each case the SE of the mean was $<12 \%$ of the mean value. Similar findings were noted using soluble extracts of fetal liver at $133 \mathrm{~d}$ of gestation.

fractions containing the 44,000 -mol wt protein yielded a radioactive hormone-receptor complex with a molecular weight of 67,000 , indicating that the $44,000-\mathrm{mol} w \mathrm{wt}$ protein contained specific oPL binding activity; and fifthly, the molecular weight of the purified PL receptor $(44,000 \pm 2,000)$ is similar or identical to that of the oPL binding site in sheep liver microsomes $(38,000-47,000)$ determined previously $(23,25)$ by affinity cross-linking techniques. The molecular weight of the PL receptor estimated by Sepharose chromatography was higher $(130,000)$ than that estimated by SDS-PAGE because the receptor may have migrated on Sepharose as a component of a Triton-protein micelle.

Whereas the PL receptor has an apparent molecular weight of $44,000 \pm 2,000$, the $\mathrm{GH}$ receptor detected in human adult liver (34) and in tissues of postnatal rabbits $(30,34)$, rats $(35$, 36 ), mice $(37)$, and sheep $(23,25)$ has a molecular weight of 108,000-130,000 (34). A GH binding site of lower molecular weight $(50,000-80,000)$ identified in rabbit $(38,39)$ and sheep $(23,25)$ liver and in rabbit $(38)$ and human $(40,41)$ serum appears to represent the extracellular GH-binding domain cleaved from the $\mathrm{GH}$ receptor by proteolysis at or near the receptor transmembrane region $(30,34)$. While the molecular weight of the PL receptor differs from that of the GH receptor, the molecular weight of the PL receptor is similar to that of prolactin receptors $(32,000-41,000)$ purified from rabbit mammary gland (42) and rat liver (43). In addition, the PL

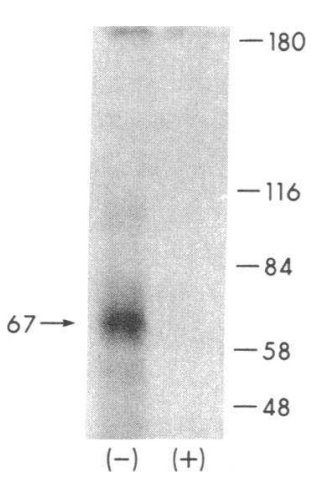

Figure 7. Cross-linking of radiolabeled oPL to the purified PL receptor. Affigel fractions containing oPL binding activity were dialyzed against $25 \mathrm{mM}$ Hepes, 10 $\mathrm{mM} \mathrm{MgCl} 2, \mathrm{pH} 7.6$, and incubated for $24 \mathrm{~h}$ at $4^{\circ} \mathrm{C}$ with ${ }^{125} \mathrm{I}$-oPL $(500,000 \mathrm{cpm}$, $\sim 0.5 \mathrm{nM})$ in the presence $(+)$ or absence $(-)$ of $1 \mu \mathrm{g}$ unlabeled oPL. Crosslinking of the radiolabeled hormone to the PL receptor was performed using 0.4 mM disuccinimidyl suberate as described in Methods. The reaction mixtures were analyzed on a $7.5 \%$ SDS-polyacrylamide gel under reducing conditions. receptor, like the prolactin receptor (42-44), does not appear to be linked by interchain or intrachain disulfide bonds. These findings suggest that the PL receptor may be structurally related to the prolactin receptor.

The PL, GH, and PRL receptors are distinguished by their differing affinities for PL, GH and PRL. Like the PL binding site detected in microsomal fractions of human fetal liver (24), the PL receptor purified from sheep liver has high affinity for PL $\left(K_{d} 0.5 \mathrm{nM}\right)$ but low affinity for GH and PRL. In contrast, $\mathrm{GH}$ (somatotropic) receptors in the sheep and in other mammals have high affinity for the mammalian growth hormones and the ovine and caprine placental lactogens but low affinity for the mammalian PRLs and the primate PLs (18, 20, 21). PRL (lactogenic) receptors preferentially bind prolactin and other "lactogenic" hormones such as human GH and human PL but have low affinity for "somatotropic" hormones such as oGH and bovine $\mathrm{GH}(18,19)$.

The PL, GH, and PRL receptors are also distinguished by striking differences in expression during ontogeny. Specific PL binding sites are detected in the liver of the fetal lamb $(8,22$, $23,25)$ and fetal mouse (45) and in the liver and skeletal muscle of the human fetus (24). In contrast, there is little or no specific binding of radiolabeled GH or PRL to human fetal skeletal muscle (24) or to tissues of the fetal rat, rabbit, rhesus monkey, mouse, or sheep $(8,22,46-50)$. Specific $\mathrm{GH}$ binding sites are detected in low concentrations in microsomal fractions of human fetal liver (24). After birth, the binding of $\mathrm{GH}$ to human liver and to other mammalian tissues increases markedly $(8,21,22,46,47,50)$.

Changes in the expression of PL and GH receptors may mediate changes in the hormonal control of growth during the transition from fetal to postnatal life. The presence of distinct PL receptors in fetal tissues provides a mechanism whereby PL may exert direct anabolic effects on fetal amino acid and carbohydrate metabolism and may stimulate fetal somatomedin production. On the other hand, GH does not acquire somatotropic activity until a new and distinct $\mathrm{GH}$ receptor emerges after birth. Since the biological actions of PL in fetal tissues are similar to the effects of $\mathrm{GH}$ in postnatal tissues, the presence of distinct fetal PL receptors implicates a role for PL as a "fetal GH."

A role for PL as a "maternal GH" during pregnancy is suggested by studies demonstrating that PL has GH-like effects on carbohydrate and lipid metabolism and stimulates insulinlike growth factor I production in pregnant rats $(1,2,51)$. Our studies in the sheep indicate that maternal liver contains both PL and GH receptors. Since oPL binds with high affinity to $\mathrm{GH}$ as well as PL receptors, the biological actions of PL in tissues of the pregnant sheep may be mediated through binding to PL and/or GH receptors.

In summary, we have purified and characterized a distinct PL receptor, a new member of the GH/PRL receptor family. The PL receptor differs from previously characterized somatotropic $(\mathrm{GH})$ and lactogenic (PRL) receptors in structure, function, and expression during ontogeny and may play a role in the regulation of maternal metabolism and the control of fetal growth.

\section{Acknowledgments}

The authors thank Larry Kodack for technical assistance, Carol Dehamer for secretarial aid, and Drs. Randall Richards and Stuart Handwerger for critical review of the manuscript. 
The work was supported by grants HD-00656 and HD-07447 from the National Institutes of Health, a Basil O'Conner Award (5-503), and Basic Research Grant (1-1104) from the March of Dimes.

\section{References}

1. Grumbach, M. M., S. L. Kaplan, J. J. Sciarra, and I. M. Burr. 1968. Chorionic growth hormone-prolactin (CGP): secretion, disposition biologic activity in man, and postulated function as the "growth hormone" of the second half of pregnancy. Ann. N.Y. Acad. Sci. 148:501-531.

2. Kaplan, S. L., and M. M. Grumbach. 1981. Chorionic somatomammotropin in primates: secretion and physiology. In Fetal Endocrinology. M. J. Novy and J. A. Resko, editors. Academic Press, Inc., New York. 127-140.

3. Freemark, M., and S. Handwerger. 1983. Ovine placental lactogen, but not growth hormone, stimulates amino acid transport in fetal rat diaphragm. Endocrinology. 112:402-404.

4. Hill, D. J., C. J. Crace, A. J. Strain, and R. D. G. Milner. 1986. Regulation of amino acid uptake and deoxyribonucleic acid synthesis in isolated human fetal fibroblasts and myoblasts: effect of human placental lactogen, somatomedin-C, multiplication-stimulating activity, and insulin. J. Clin. Endocrinol. Metab. 62:753-760.

5. Freemark, M., and S. Handwerger. 1984. Ovine placental lactogen stimulates glycogen synthesis in fetal rat hepatocytes. Am. J. Physiol. 246:E21-24.

6. Freemark, M., and S. Handwerger. 1984. Synergistic effects of ovine placental lactogen and insulin on glycogen metabolism in fetal rat hepatocytes. Am. J. Physiol. 247:E714-E718.

7. Freemark, M., and S. Handwerger. 1985. Ovine placental lactogen inhibits glucagon-induced glycogenolysis in fetal rat hepatocytes. Endocrinology. 116:1275-1280.

8. Freemark, M., and S. Handwerger. 1986. The glycogenic effects of placental lactogen and growth hormone in ovine fetal liver are mediated through binding to specific fetal oPL receptors. Endocrinology. 118:613-618.

9. Hurley, T. W., P. Thadani, C. M. Kuhn, S. M. Schanberg, and S. Handwerger. 1980. Differential effects of placental lactogen, growth hormone and prolactin on rat liver ornithine decarboxylase activity in the perinatal period. Life Sci. 27:2269-2276.

10. Hill, D. J., C. J. Crace, and R. D. G. Milner. 1985. Incorporation of ${ }^{3} \mathrm{H}$-thymidine by isolated fetal myoblasts and fibroblasts in response to human placental lactogen (hPL): possible mediation of hPL action by release of immunoreactive SM-C. J. Cell. Physiol. 125:337-344.

11. Strain, A. J., D. J. Hill, I. Swenne, and R. D. G. Milner. 1987. The regulation of DNA synthesis in human fetal hepatocytes by placental lactogen, growth hormone and insulin-like growth factor I/somatomedin-C. J. Cell. Physiol. 132:33-40.

12. Adams, S. O., S. P. Nissley, S. Handwerger, and M. M. Rechler. 1983. Developmental patterns of insulin-like growth factor I and II synthesis and regulation in rat fibroblasts. Nature (Lond.). 302:150153.

13. Swenne, I., D. J. Hill, A. J. Strain, and R. D. G. Milner. 1987. Effects of human placental lactogen and growth hormone on the production of insulin and somatomedin C/insulin-like growth factor I by human fetal pancreas in tissue culture. J. Endocrinol. 113:297-308.

14. Gluckman, P. D., M. M., Grumbach, and S. L. Kaplan. 1981. The neuroendocrine regulation and function of growth hormone and prolactin in the mammalian fetus. Endocr. Rev. 2:363-395.

15. Parkes, M. J., and D. J. Hill, 1985. Lack of growth hormonedependent somatomedins or growth retardation in hypophysectomized fetal lambs. J. Endocrinol. 104:193-199.

16. Palmiter, R. D., G. Norstedt, R. E. Gelinas, R. E. Hammer, and R. L. Brinster. 1983. Metallothionein-human GH fusion genes stimulate growth of mice. Science (Wash. DC). 222:809-814.
17. Hill, D. J., C. J. Crace, L. Fowler, A. T. Holder, and R. D. G. Milner. 1984. Cultured fetal rat myoblasts release peptide growth factors which are immunologically and biologically similar to somatomedin. J. Cell. Physiol. 119:349-358.

18. Lesniak, M. A., P. Gordon, and J. Roth. 1977. Reactivity of non-primate growth hormones and prolactins with human growth hormone receptors on cultured human lymphocytes. J. Clin. Endocrinol. Metab. 44:838-849.

19. Shiu, R. P. C., P. A. Kelly, and H. G. Friesen. 1973. Radioreceptor assay for prolactin and other lactogenic hormones. Science (Wash. DC). 180:968-971.

20. Tsushima, T., and H. G. Friesen. 1973. Radioreceptor assay for growth hormone. J. Clin. Endocrinol. Metab. 37:334-337.

21. Carr, D., and H. G. Friesen. 1976. Growth hormone and insulin binding to human liver. J. Clin. Endocrinol. Metab. 42:484-493.

22. Freemark, M., M. Comer, and S. Handwerger. 1986. Placental lactogen and growth hormone receptors in sheep liver: striking differences in ontogeny and function. Am. J. Physiol. 251:E328-333.

23. Freemark, M., M. Comer, G. Korner, and S. Handwerger. 1987. A unique placental lactogen receptor: implications for fetal growth. Endocrinology. 120:1865-1872.

24. Hill, D. J., M. Freemark, A. J. Strain, S. Handwerger, and R. D. G. Milner. 1988. Placental lactogen and growth hormone receptors in human fetal tissues: relationship to fetal plasma human placental lactogen concentrations and fetal growth. J. Clin. Endocrinol. Metab. 66:1283-1290.

25. Freemark, M., and M. Comer. 1988. Differential solubilization of placental lactogen and growth hormone binding sites in sheep liver: further evidence for a distinct placental lactogen receptor in fetal and maternal liver. Endocrinology. 122:2771-2779.

26. Hurley, T. W., S. Handwerger, and R. E. Fellows. 1977. Isolation and structural characterization of ovine placental lactogen. Biochemistry. 16:5598-5603.

27. Freemark, M., and S. Handwerger. 1982. Ovine placental lactogen stimulates amino acid transport in rat diaphragm. Endocrinology. 110:2201-2203.

28. Laemmli, U. K. 1970. Cleavage of structural proteins during the assembly of the head bacteriophage T. Nature (Lond.). 227:680685 .

29. Oakley, B. R., D. R. Kirsch, and N. R. Morris. 1980. A simplified ultrasensitive sliver stain for detecting proteins in polyacrylamide gels. Anal. Biochem. 105:361-363.

30. Spencer, S. A., R. G. Hammonds, W. J. Henzel, H. Rodriguez, M. J. Waters, and W. I. Wood. 1988. Rabbit liver growth hormone receptor and serum binding protein: purification, characterization and sequence. J. Biol. Chem. 263:7862-7867.

31. Munson, P. J., and D. Rodbard. 1980. LIGAND: a versatile computerized approach for the characterization of ligand binding systems. Anal. Biochem. 107:220-239.

32. McPherson, G. A. 1985. Analysis of radioligand binding experiments: a collection of computer programs for the IBM PC. $J$. Pharmacol. Methods. 14:213-220.

33. Bradford, M. M. 1976. A rapid and sensitive method for the quantitation of microgram quantities of protein utilizing the principle of protein-dye binding. Anal. Biochem. 72:248-254.

34. Leung, D. W., S. A. Spencer, G. Chachianes, R. G. Hammonds, C. Collins, W. J. Henzel, R. Barnard, M. J. Waters, and W. I. Wood. 1987. Growth hormone receptor and serum binding protein: purification, cloning and expression. Nature (Lond.). 330:537-543.

35. Donner, D. B. 1983. Covalent coupling of human growth hormone to its receptor on rat hepatocytes. J. Biol. Chem. 258:27362743.

36. Carter-Su, C., J. Schwartz, and G. Kikuchi. 1984. Identification of a high affinity growth hormone receptor in rat adipocyte membranes. J. Biol. Chem. 259:1099-1104.

37. Smith, W. C., and F. Talamantes. 1987. Identification and characterization of a heterogeneous population of growth hormone 
receptors in mouse hepatic membranes. J. Biol. Chem. 262:22132219.

38. Barnard, R., and M. J. Waters. 1986. Serum and liver cytosolic growth hormone binding proteins are antigenically identical with liver membrane "receptor" types 1 and 2. Biochem. J. 237:885-892.

39. Haeuptle, M. T., M. L. Aubert, J. Djiane, and J. P. Kraehenbuhl. 1983. Binding sites for lactogenic and somatogenic hormones from rabbit mammary gland and liver: their purification by affinity chromatography and their identification by immunoprecipitation and photoaffinity labeling. J. Biol. Chem. 258:305-314.

40. Baumann, G., M. W. Stolar, K. Amburn, C. P. Barsano, and B. C. DeVries. 1986. A specific growth hormone-binding protein in human plasma: initial characterization. J. Clin. Endocrinol. Metab. 62:134-141.

41. Herington, A. C., S. Ymer, and J. Stevenson. 1986. Identification and characterization of specific binding proteins for growth hormone in normal human sera. J. Clin. Invest. 77:1817-1823.

42. Kelly, P. A., J. Djiane, and M. Katoh. 1984. The interaction of prolactin with its receptors in target tissues and its mechanism of action. Recent Prog. Horm. Res. 40:379-439.

43. Boutin, J. M., C. Jolicoeur, H. Okamura, J. Gagnon, M. Edery, M. Shirota, D. Banville, I. Dusanter-Fourt, J. Djiane, and P. A. Kelly. 1988. Cloning and expression of the rat prolactin receptor, a member of the growth hormone/prolactin receptor gene family. Cell. 53:69-77.
44. Katoh, M., J. Djiane, and P. A. Kelly. 1985. Prolactin-binding components in rabbit mammary gland: Characterization by partial purification and affinity labeling. Endocrinology 116:2612-2620.

45. Harigaya, T., W. C. Smith, and F. Talamantes. 1988. Hepatic placental lactogen receptors during pregnancy in the mouse. Endocrinology. 122:1366-1372.

46. Posner, B. 1976. Characterization and modulation of growth hormone and prolactin binding in mouse liver. Endocrinology. 98:645-654.

47. Kelly, P. A., B. I. Posner, and T. Tsushima. 1974. Studies of insulin, growth hormone and prolactin binding: ontogenesis, effects of sex and pregnancy. Endocrinology. 95:532-539.

48. Dhanireddy, R., and R. E. Ulane. 1984. Prolactin binding in the developing rat fetal liver. Life Sci. 35:733-740.

49. Josimovich, J. B., K. Merisko, L. Bocella, and H. Tobon. 1977. Binding of prolactin by fetal rhesus cell membranes. Endocrinology. 100:557-563.

50. Gluckman, P. D., J. H. Butler, and T. B. Elliott. 1983. The ontogeny of somatotropic binding sites in ovine hepatic membranes. Endocrinology. 112:1607-1612.

51. Pilistine, S. J., A. C. Moses, and H. N. Munro. 1984. Placental lactogen administration reverses the effect of low-protein diet on maternal and fetal serum somatomedin levels in the pregnant rat. Proc. Natl. Acad. Sci. USA. 81:5853-5857. 